\title{
$\widehat{A}$ Madridge
}

madridge Journal of Behavioral and Social Sciences

Interconnecting Scientific World

Review Article

Open Access

\section{A Comparative analysis of Recent U.S. Policies in the Middle East: Obama vs. Trump}

\author{
Behrooz Kalantari ${ }^{\star}$ \\ Professor, Department of Political Science and Public Affairs, Savannah State University, USA
}

\section{Article Info}

\author{
*Corresponding author: \\ Behrooz Kalantari \\ Professor \\ Department of Political Science and Public \\ Affairs \\ Savannah State University \\ USA \\ Tel: (912) 358-3215
}

E-mail: Kalantab@savannahstate.edu

Received: June 12, 2018

Accepted: July 11, 2018

Published: July 17, 2018

Citation: Kalantari B. A Comparative analysis of recent U.S. Policies in the Middle East: Obama vs. Trump. Madridge J Behav Soc Sci. 2018: 2(1): 41-46.

doi: 10.18689/mjbss-1000107

\begin{abstract}
Copyright: $\odot 2018$ The Author(s). This work is licensed under a Creative Commons Attribution 4.0 International License, which permits unrestricted use, distribution, and reproduction in any medium, provided the original work is properly cited.
\end{abstract}

Published by Madridge Publishers
Keywords: Recognition; Movement; Ideology; Nuclear activities; Negotiations.

\section{Introduction}

Traditionally the Middle East has been the most important and challenging part of the American foreign policy. After the creation of the state of Israel and prominence of US as a super power after World War II, this challenge has continuously emerged as the most critical one. In general, it can be argued that American foreign policy towards the Middle East during the Cold War was based on a realistic model. In those days the U.S. had three major objectives: containing the Soviet Union, protecting the State of Israel and most importantly, preserving access to the Middle East oil. In line with all those objectives and especially with the Soviet containment, the U.S. tried hard to prevent any in-state wars because through such conflicts the Soviet Union was able to extend her influence in the area [1].

Before the 9/11 attack and invasion of Iraq, the Israeli-Palestinian conflict was the most difficult to balance the need for oil and the security of the state of Israel. After the invasion of Iraq which is considered one of the major foreign policy mistakes by the USA, as well as the creation of ISIS and war in Syria, terrorism overshadowed the IsraeliPalestinian issue. However, it still remains the most important root of the problems in the Middle East. Every past administration up-to Trump has tried to make use of the most trained and experienced member of its administration to deal with this complex area. And in some cases, the United States has been very successful in dealing with some of the Middle Eastern prominent issues. For example, in 1978, Egyptian President Anwar Sadat, Israeli Prime Minister Menachem Begin, and U.S. President Jimmy Carter signed the Camp David Accords in Washington. This agreement was the most important accomplishment of American government that brought a lasting peace between Egypt and Israel. Also in 1994, Yitzhak Rabin, the Prime Minister of Israel, and Yasir Arafat, the chairman of the P.L.O., and President Clinton signed a declaration of principle in Washington sealing the first agreement between Jews and Palestinians for Palestinian self-rule. Although there are several countries exist in the Middle East, it can be argued that at the present time only three countries, due to their capabilities, interests, and ambitions, influence the events profoundly in the area. They include: Israel, Iran, and Saudi Arabia and can be called the major players in the area.

\section{The United States and Israel}

Israel has been always the most significant player in the area since its existence in 1948. She has always been looking for opportunities to shape the events according to her own interests, and the most important issue for Israel has always been security. Israel was originally founded on the ideology of Zionism. As an organized movement, 
Zionism started by Theodor Herzl in 1897 in Europe and its goal was to find a homeland for the European Jews. During WWI and after WWII, due to mistreatment and especially the Holocaust, many Jews migrated to Palestine that was under British control. In 1948, David Ben-Gurion, the head of the Jewish Agency and a lifelong Zionist activist, proclaimed the establishment of the State of Israel in Palestine. U.S. President Harry S. Truman recognized the new nation ten minutes after its creation. The goal of Ben-Gurion was to create a new state in the image of an old civilization that existed thousands of years ago. Therefore, the Zionists found a new independent political entity called Israel in the land of Palestine [2].

Since the recognition of the state of Israel, the US has been the major unconditional supporter of Israel and assisted them with military and monetary help on a regular and annual basis. According to statistics, "U.S. government subsidies to Israel total over $\$ 140$ billion since 1949 . This makes Israel by far the largest recipient of American giveaways since World War II [3]. In addition, the "military and economic benefits are not the ends of the story. The American government also works hard to shield Israel from the international political and legal consequences of its policies and actions" [3]. The U.S. spends a great amount of its political capital to defend Israel's behavior in the Middle East. For example, only last week in April 2018, U.S. was isolated in U.N. Security Council for defending Israel in killing over sixty Palestinian demonstrators in Gaza. Also, however, vetoed the anti-Israeli resolution that condemned Israel. Later, U.S. draft resolution on condemning Hamas in the Security Council did not receive any support from the Council which is considered a political defeat for the U.S.

This unconditional support has caused a great deal of animosity and negative feelings towards the U.S. by the Arabs and Moslems towards American Middle East policies. This negativity came to its climax with the election of George Bush and his invasion of Iraq. Taking into consideration that Iraq was the most important supporter of Palestinians in their conflict against Israel, it created more hostility towards the U.S., more specifically, by the Palestinians. After the election of Obama and winning the Nobel Peace Prize, the image of the U.S. started to change in a positive direction in the world, and especially in the Middle East. However, the only country that Obama was not popular about U.S. policies was Israel, although the majority of the American Jews voted for him in the presidential election. Due to ideological orientation of Netanyahu's government, Obama lacked any influence over Israeli government in preventing her to build illegal settlements in the West Bank. As a result, he was not able to capitalize on U.S. resources to bring a more lasting peace in the Middle East [4]. The US assistance and policy towards Israel is driven by the assumption of creating a balance of power between Israel and other countries in the region. The U.S. policy towards Israeli revolves around the assumption that Israel has to have definite military superiority over other countries in the area in order to keep its security intact [5].

Unfortunately, the Israeli behavior in the Middle East has caused so much negativity towards the US that when the people in the Middle East are given the chance to have democratic elections in different countries, they elect people who are the list friendly to the U.S. For example, election of Moslem Brotherhood in Egypt after resignation of Mubarak in 2011, and the victory of Hamas in legislative elections in the West Bank and Gaza on January 2006 are the best indication of their frustration with the U.S. This happened when Hamas openly calls for the destruction of Israel. Another example is the strong support of Hezbollah in Lebanon's election year after year as a major political force in the country. All these examples are clear indications of the fact that U.S. policies are failing in the Middle East and the people of the region are against them [6].

\section{Iran (Shi'ism) and the Middle East}

Iran is home to the most powerful center of Shi'a Islam with $96 \%$ of its 80 million belong to Shi'a sect. During the eightyear war with Iraq, Iran was home to Iraq's Shi'a opposition groups who were trained and financed by Iran to fight Saddam Hossein. It is important to notes that Majority of Iraqis belonged to the Shi'a sect of Islam while Saddam Hossein was a Sunni Moslem. After the invasion of Iraq by the U.S. and removal of Saddam, the opposition groups stationed in Iran went back to Iraq to take over the country, therefore, Iranian influence in Iraq increased drastically. Later on Iran, as the leader of Shi'a Islam, involved itself with the war in Syria by supporting Bashar AlAssad who also belongs to one of the branches of Shi'a Islam, although Syria's official government was a secular one.

Internal politics in Iran is to some extent complex and needs close attention in order to understand its dynamics. Iranian politics is very much polarized between two major opposing forces. The first group which is a minority in the country, called (Fundamentalists) has a tremendous amount of power with little support from the people. Their power is more due to the structure of the political system that grants a large amount of power to unelected officials. The other side is the Reformist forces with much less power but a tremendous amount of popular support. Ahmadi Nijad (former Iranian President), represented by the first group and the present President (Rouhani) represents a totally different mentality in their relationship with the West, more importantly the U.S. The Fundamentalists believe that they should never trust the United States and never negotiate with her and since she is considered to always be the enemy of Iran. On the contrary, the Reformists believe that Iran should normalize her relations with the US and resolve her conflicts through negotiation and compromise. Rouhani was elected into the office in 2013 with the promise of resolving the conflicts with the U.S. and normalizing Iranian policies towards the West in all areas of concern. Among the six candidates in the presidential election, he received $57 \%$ of the total vote. This shows that regardless of the power of the Fundamentalists, the people showed their resolve to break the atmosphere of animosity and conflict between the US and Iran.

The Joint Comprehensive Plan of Action (JCPOA) agreement is the most significant achievement between Iran and the 
world community. It originally started about 13 years ago by the European Unions and for the last stage of this agreement it took over two years of intense direct negotiations between foreign ministers of Britain, France, Germany, Russia, China, the UN, the European Union, and the United Nations. The IAEA (International Atomic Energy Agency) was also in the lope concerning all the negotiations. The IAEA is part of the United Nations, and the world's center for cooperation in the nuclear field and a watch dog for supervising the violations of nuclear activities around the world. The only person who was against this agreement and tried hard to disrupt it was Mr. Netanyahu Prime Minister of Israel.

\section{Saudi Arabia (Wahhabism) and the Middle East}

Saudi Arabia with its tremendous amount of wealth due to its oil revenues, small population, and promoter of the Wahhabi sect of Islam, plays an important role in the Middle East. There are two major sects in Islam, one is Sunni and the other is Shi'a which is considered the minority group. These two sects also have other branches within themselves as well. However, there are two major structural differences between those two sects. There is no hierarchical structure in Sunni Islam and anyone with some degree of authority can issues Fatwa (religious decree). However, Shi'a Islam is very much like Catholicism in Christianity with a clear hierarchy, and only the highest in the rank (Ayatollahs) can issue a fatwa. This issue becomes very critical when it comes to issuing a fatwa for military reasons such as Jihad or suicide attempts to kill others. Osama Bin Laden was not only the religious authority but the political leader of Al-Qaida with no religious education and experience, however, as a Sunni Moslem, he was able to issue Fatwa.

Within the Sunni set of Islam, there is another sect called Wahhabism which started by Muhammad ibn Abd al-Wahhab (1703-1792). It is an ultra-conservative puritan movement that advocates returning to the original Islam and disregards all changes that have happened to Islam since its inception. Later in 1932, Abd-al-Wahhab formed an alliance with a local worrier, Muhammad bin Saud to set up a government that is based on his teachings and was called Saudi Arabia. They consider anyone who is outside Sunni sect of Islam, "Kafir" which is an Arabic word for "infidel" and those who do not believe in the teaching of the Prophet of Islam. Accordingly, the Kafirs either have to accept the doctrine of Islam (Wahhabism) or be murdered. This movement later spread to other Persian Gulf Arab States including United Arab Emirate and Qatar. Saudi Arabia, with its tremendous amount of wealth, has been spending millions of dollars to spread the message of Wahhabism under the cover of true Islam. Especially after the Islamic revolution in Iran which was predominately a Shi'a revolution, Saudis have been looking for an opportunity to export their belief to compete with Iran. It is critical to understand that the "roots and spread of violent Sunni jihad lead back to Saudi Arabia and its Wahhabicentered clerical establishment" [6].
As indicated earlier, after the invasion of Iraq, which is also a predominately Shi'a country, and was run by Saddam Hussein who was a Sunni, Iranian influence in Iraq increased. This Phenomenon made Saudis very angry since they were worried about the increase of Iranian influence in the region. The next development was the advent of the Arab Spring in the region that affected several countries including Syria which was also run by a Shi'a leader (Bashar Assad). With the weakening of Assad's regime, an opportunity and power vacuum was created for Saudis to fill in. Therefore Saudis provided an abundant amount of seed money as well as the large-scale supply of weapons and ammunition to many rebel groups such as the Army of Conquest, the al-Nusra Front, an al-Qaeda affiliated group as well as ISIS. Those weapons were mostly purchased from Eastern European countries such as Croatia and many former Yugoslav states who manufactured heavy arsenals.

When King Abdullah of Suadi Arabia died in January of 2015, his Brother Salman became the new King. He immediately appointed Prince Muqrin who was the son of Abdulaziz Al- Saud as his heir but he was to be replaced three months later by Muhammad bin Nayef who was King Salman's Nephew. However, in June 2017 he was also removed from power and his own son Mohammad bin Salman was appointed to be the new heir to the throne. Mohammad also held his previous position as the Minister of defense at the age of 31 . As soon as the new Prince assumed power he launched an invasion of Yemen to influence the outcome of the Yemeni Civil War in favor of the government of President Abdrabbuh Mansur Hadi. The rebels are Shi'a Houthis loyalists to former President of Yemen, Ali Abdullah Saleh. Houthis are part of a minority sect within Shi'a sect of Islam who are asking for power sharing in the Yemen's government. This invasion has devastated the life in Yemen with up-to 10,000 civilian death and has brought destruction of the infrastructure of the country and spread of different diseases such cholera and it is threatening the life of the millions of people. In March 2011 Saudi Arabia also invaded Bahrain to assist the Bahraini regime in suppressing an anti-government uprising in the country. In Bahrain a minority of $20 \%$ Sunnis represented by Al-Khalifah family, is oppressing the Shi'a minority in the country. In January of 2016, Saudi Arabia executed 47 of its citizens after being convicted of terrorism offences. This included Sheikh Nimr al Nimr, leader of the Shi'a sect in Saudi Arabia who was a vocal supporter of the anti-discrimination charges against the government since 2011. Sheikh Nimr never participated in any arm struggle against the government.

\section{Overall Middle Easterner's Perception about the United States}

Most Middle Easterners see the United States as the close partner of Israel and consider Israel as the 51st state of the United States. Therefore, any Israeli behavior that is harmful to the people of the area, its discredit always goes to the U.S. In addition, those Middle Eastern leaders who are close allies of the U.S. are not considered the most popular heads of the 
states in the region. As a result, one way for the Middle Eastern leaders to project independence and popularity is to oppose U.S. and Israeli policies in the area. In some cases, the most brutal regimes in the Middle East, in order to gain some popularity, severely oppose the U.S. and Israeli governments and support and help the Palestinians (such as Saddam Hossein of Iraq and Kaddafi of Libya). In fact, "in the 2006 Annual Arab Public Opinion Survey, conducted in six countries (Egypt, Jordan, Lebanon, Morocco, Saudi Arabia, and the UAE), fully 72 percent of those surveyed saw the United States as the biggest threat to them, second only to Israel, seen by 85 percent as the biggest threat" [2]. In another survey in 2008, in the Annual Public Opinion, 83 percent of the respondents had a negative opinion of the U.S. This attitude was changed by the election of Obama to 77 percent in 2009 [2].

\section{Obama's Policies in the Middle East}

George Bushes' disastrous policies in the Middle East surpassed any U.S. President to outrage the people in the area and elevated their dislike for the U.S. government to an unprecedented level. However, the election of Barak Obama brought new hopes and a new worldview which relied on the rule of international law and engagement with the people of the Middle East. Obama's emphasis was on the importance of diplomacy over the use of force to resolve the conflicts in the Middle East. In his first speech that addressed the Islamic world in Egypt, he emphasized that US is a friend and a partner of Moslems in building a peaceful region, and emphasized on U.S. support for democracy and human rights [7]. According to this new policy, U.S. tried to be more of an honest mediator and broker between the conflicting parties by assisting local surrogates to take over responsibility to provide security in their own backyard. His policies deemphasized the use of military and replaced it with 'soft power' and diplomacy with the allies, supporters, and enemies [8]. In addition, the Obama administration concentrated on the issue of counterterrorism and protecting the U.S. from extremist attacks (Almeida, 2017). Some argue that during Obama administration, U.S. policies in the region have been based on disengagement from the issues. This cannot be true; it has been recalibration rather than retrenchment. In addition, as for U.S. relationship with Israel, regardless of Israel's lack of cooperation and even hostility towards the U.S. on the Nuclear Deal with Iran, Obama administration has been the most generous administration to assist Israel. Before leaving office Obama "signed off on a record-setting agreement with the Israelis to provide them $\$ 38$ billion over the next 10 years-a level of cooperation between our military and security services that has never happened before" [9].

For the first time in the history of the United States after President Carter's historic move, Obama administration adopted policies that truly took American interests into consideration in dealing with Middle Eastern conflicts. Obama's approach was based on having a deep understanding of the new realities of the region and recognizing the changing nature of the events in the area. Obama realized that in order to create a long-lasting peace in the area, it has to be built on the previous U.S. efforts to bring peace to the area, including the 1993 Oslo Accord between the Israelis and Palestinians as well as the "two-state" doctrine. He tried to stop Israelis from building illegal settlements in the West Bank that belongs to Palestinians and bring two sides together to build a lasting peace accord. However, Israel's resistance and disregard for international law crippled Obama's original intent. Obama's another rational approach was based on normalization of relations with Iran that was perceived as developing nuclear arms. Obama was able to impose international economic sanctions on Iran in order to bring her to the negotiation table. His efforts were successful and led to the signing of the Joint Comprehensive Joint Comprehensive Plan of Action (JCPOA) as the base for further negotiations in other areas of concern.

The other country besides Israel that Obama tried not to have a cozy relationship was Saudi Arabia. Obama understood the dangers of the Wahhabi doctrine and Saudi Arabia's intention to spread it through the Middle-East as well as the world. This ideology was the ideology that created Taliban in Afghanistan and Bin Laden, the leader of Al-Qaeda, as well as terrorist organizations such ISIS. Actually, all the terrorists who hit the Tween Towers in New York City belonged to Wahhabi sect and 19 of them were from Saudi Arabia.

\section{Trump's Policies in the Middle East}

President Trump's hawkish policies of militarism and onesided view of Middle East issues, as well as his burning desire to dismantle Obama's achievements, has engulfed the Middle East with major and fundamental new problems. In addition, his naïve understanding of the area's politics has destroyed most of the U.S. accomplishments in the region and smashed hopes for achieving peace and stability in the area for the near future. His unrealistic and one-sided policies have severely damaged any hope for peace and made the area more prone to war and conflict. He appointed his son-in-law Jared Kushner with no experience or education about the region as his advisor on the Middle East and asked him to handle the most complex political Issues in the world.

Barak Obama brought new hopes and a new worldview which relied on the rule of international law and engagement with the people of the Middle East. Obama's emphasis was on the importance of diplomacy over the use of force to resolve the conflicts in the Middle East. In his first speech that addressed the Islamic world in Egypt, he emphasized that US is a friend and a partner of Moslems in building a peaceful region, and emphasized on U.S. support for democracy and human rights [7]. According to this new policy, U.S. tried to be more of an honest mediator and broker between the conflicting parties by assisting local surrogates to take over responsibility to provide security in their own backyard. His policies deemphasized the use of military and replaced it with 'soft power' and diplomacy with the allies, supporters, and enemies [8]. In addition, the Obama administration concentrated on the issue of counterterrorism and protecting the U.S. from extremist attacks. 
The best example of his mismanagement of events is the recognition of Jerusalem as the capital of Israel that brought outrage and disappointment to Palestinians as well as Arabs and Moslems around the world. This action not only did not have any positive effect on the peace process between the Palestinians and Israelis but caused the Palestinians to abandon the U.S. as the mediator in the peace process and are not willing to come back to the peace negotiations. As one author rightfully put it, "the torrent of complex problems that Donald Trump has unleashed by his recognition of Jerusalem as Israel's capital will plague U.S. policy and the Middle East peacemaking for many years" [10].

Another major policy that surprised most of the world leaders and experts, was the violation of the international agreement on a nuclear deal with Iran (JCOPA). This decision was a clear violation of international law and weakened the status and prestige of the U.S. as well as international organizations such as United Nations and IAEA, as well as the European Union and UN Security Council, in the eyes of the world. The JCPOA is an international agreement that is the result of over twelve years of negotiations between the European Union with Iran, as well as two years of intense diplomacy between Iran, U.S., France, Britain, Germany, Russia, China, Germany, as well as the European Union. Unilateral violation and rejection of such an international agreement portrays the U.S. as an international rouge and questions its credibility and respect for international law.

Mr. Trump greatly values the Prime Minister of Israel, Mr. Netanyahu. He is the leader of the Likud party in Israel that has impeded all President Obama's attempts to bring peace to the Middle East by violating the International Law for building new settlements in the West Bank. There have been 226 UN Security Council resolutions that relate to Israel and most of the recent ones condemn Israel for violation of Palestinian rights and building illegal settlements in the West Bank. Unfortunately, the U.S. has vetoed all those resolutions and took the responsibility for Israel's illegal actions. However, during President Obama, the United States did not veto the UN resolution 2334 which condemned Israel for its illegal settlement activities in the West Bank. By the U.S. abstaining from that resolution it sent a message to Israel that it has to take responsibility for her own actions. Mr. Netanyahu also tries to delay the negotiations on the "two-state" solution and at the same time expands illegal settlements in the West Bank to a monstrous proportion. As far as Netanyahu's domestic reputation in Israel is concerned, presently he and his family are under investigation for corruption and illegal activities.

Trump's new policy of engagement in the Middle East has manifested itself in a total support for the wealthiest and Wahhabi countries of the region including Saudi Arabia and Persian Gulf Emirates of United Arab Emirate, Qatar, and Bahrein. In addition, America's unconditional support for Israel and strong opposition to Iran is the foundation of his policies. Due to this doctrine, the major problems of the Middle East remain intact and Palestinians who are the core reason for Middle Eastern conflict do not get any attention.
This "policy unfolds against the backdrop of the Obama legacy, which has "rightsized" America's role in the Middle East, leaving local partners and allies widely to their own devices to solve their own problems". Due to the complexity of the issues of the region and simplified, naïve, and unrealistic policies of Trump administration, U.S. will come out as a major loser from the Middle Eastern quagmire. Mr. Trump's decisions have made the U.S. look untrustworthy and unreliable partner in international negotiations and agreements with not honoring her signature and commitments. Presently every country in the world except Israel has shown their disappointment about this U.S. policy in the areas.

President Trump's doctrine is to defend Saudi Arabia's policy of genocide in Yemen. On May 20th, 2017, he signed a $\$ 350$ billion arms deal with Saudis which included the delivery of all kinds of sophisticated American Arms which is unprecedented in the American history. In addition, some also question the composition of the Trump administration as being similar to a military junta. They argue that it undermines the fundamental of civilian rule in the United States [11]. Some of Mr. Trump advisors have more sympathy for Israel than the U.S., For example, prominent American advocates of Israel, including Alan Dershowitz, an informal Trump adviser, and Mort Klein, president of the Zionist Organization of America, who is a longtime ally of White House national security adviser John Bolton.

\section{Trump and Kurds}

The Kurds are largest ethnic minority in Syria, comprising around $7 \%$ to $10 \%$ of the country's population. They have been the most important U.S. ally in U.S. war against ISIS and fought hard to defeat her along with the United States. In fact without Kurd's cooperation, it would not be possible for the U.S. to fight ISIS through only aerial bombardment. There had to be a strong ground force to conduct the actual fighting with the enemy face to face. The Kurds provided that crucial support for the U.S. and lost a great number of their fighters during many ground battles against ISIS. However, due to their relationship with Iran, they did not show any open hostility towards that country regardless of U.S. pressure to do so [12]. After ISIS was defeated and its capital Raga was captured in early January 2018, Turkish troops launched an aerial and ground assault on Kurdish militias in Northern Syria. In this adventure the Kurds needed weapons and assistance to fight Turks, who is also a member of NATO, but no one provided them with such an assistance. They simply cut to pieces by rabble wielding weapons and Abrams tanks furnished to them by the Americans. Trump easily abandoned closest U.S. ally in the war with ISIS. Kurds have been used the same way with authoritarian regimes to serve their interest in the past and have been sacrificed when those interests changed [13]. However, to be treated by a superpower who claims representing democratic values, this kind of behavior is a new phenomenon. 


\section{Conclusion}

This study focuses on a critical analysis between the policies of Trump and Obama administrations toward the Middle East. Historical analysis shows that U.S. has been deeply involved in the political life of the Middle East at least since the creation of the state of Israel. Besides the recent developments in the area, the major challenge for the U.S. has been the Israeli-Palestinian conflict that is considered the root of the problems in the Middle East region. Current issues in the area somehow can be traced and connected to the Palestinian problem that has captured the minds of overwhelming majority of Moslems as well as Arabs.

With the election of Barak Obama the United States introduced a new worldview which relied on the rule of international law and engagement with the people of the Middle East. Obama's emphasis was on the importance of diplomacy over the use of force as well as genuine respect for human rights. During Obama, U.S. tried to be more of an honest mediator and broker between the conflicting parties in the region. Unfortunately his views on Middle East peace did not realized partly due to the conservative and extremist policies of the Israeli government. Netanyahu launched major opposition to his policies through APAC in the United States. In addition he refused acceptance of a fair resolution of conflicts with the Palestinians.

Mr. Trump's naïve understanding of the area's politics has destroyed most of the U.S. accomplishments in the region and smashed hopes for achieving peace and stability in the area for the near future. His unrealistic and one-sided view of the events have severely damaged any hope for peace and made the area more prone to war and conflict. Trump's new policy of engagement in the Middle East has manifested itself in a total support for the wealthiest and Wahhabi countries of the region including Saudi Arabia and Persian Gulf Emirates. In addition, America's unconditional support for Israel and strong opposition to Iran is the foundation of his approach in the area. Based on this view he unilaterally left the JCPOA agreement with Iran and made the U.S. a major violator of international law. Due to this doctrine, major problems of the Middle East remain intact and Palestinians who are the core reason for Middle Eastern conflict do not get any attention.

The U.S. has been heavily supporting Israel for any behavior and activity in the area. This unbalanced policy is due to the influence of the Jewish lobby in the United State who pushes the US politics to favor Israel with no concern for the interests of the US. However, the U.S. has to realize that time is changed and there are new realities in the Middle East and it is important that we realize them and change accordingly and turn them into opportunities and advantages for U.S. interests.

The U.S. has to realize that she has been paying dearly for her previous wrong policies in the Middle East by ignoring the aspirations of the people in the Middle East region. However, when we made good decisions we also ripped the benefits. The Middle East, like any other region of the world, is composed of moderate forces as well as extremists. Mr. Trump's present policies of supporting extremists such as Netanyahu and the new Saudi King and his son in Saudi Arabia will cost the suppression of moderate forces in the area and more wars and destruction will be waiting to come. In addition, Trump's antagonism towards the present moderate government of Iran will help the extremists in that country to gain upper hand and more influence. So far in his presidency, he has not only done nothing to resolve any problem in the region but has strengthened the extremist forces in the area and has pushed back the Israeli-Palestinian issue for many years. Unfortunately, he is fanning the fire of cold war by supporting Israel and Saudi Arabia to counter Iranian influence rather than trying to de-escalate the conflicts in the region and get positively engaged with Iran. Finally, by taking side in the Yemen war and arming Saudi Arabia, he is planting a new wave of future Yemeni (Houthi) terrorism against the U.S. in the new future.

\section{References}

1. David SR. American Foreign Policy towards the Middle East: A Necessary Change?.IsraelAffairs.2006; 12(4):614-621. doi:10.1080/13537120600889886

2. Kamrava M. Modern Middle East: A Political History since the First World War. University of California Press. 2011.

3. Freeman CW. America's Continuing Misadventures in the Middle East. Charlottesville, Virginia: Just World Books. 2016.

4. Guerlain P. The Israel lobby, American democracy and foreign perceptions of the USA. Journal of Public Affairs. 2011; 11(4): 372-381. doi: 10.1002/ pa.387

5. David SR. American Foreign Policy towards the Middle East: A Necessary Change?.IsraelAffairs.2006; 12(4):614-621.doi:10.1080/13537120600889886

6. Choksy CEB, Jamsheed K. The Saudi Connection: Wahhabism and Global Jihad. World Affairs. 2015.

7. Krieg A. Trump and the Middle East: Barking Dogs Seldom Bite. Insight Turkey. 2017; 19(3): 139-158. doi: 10.25253/99.2017193.07

8. Krieg A. Externalizing the Burden of War: the Obama Doctrine and US Foreign Policy in the Middle East. International Affairs. 2016; 92(1): 97113. doi: $10.1111 / 1468-2346.12506$

9. Chollet D, Sullivan J, Simes D, Long MB. U.S. Commitments in the Middle East: Advice to the Trump administration. Middle East Policy. 2016; 24(1): 5-34. doi: 10.1111/mepo.12248

10. Khalid R. Trump's Capital Mistake. Nation. 2018; 306(1).

11. Stockwell N. Disaster Area: U.S. Policy in the Middle East. The Progressive. 2017.

12. Pereira Z. The Trump Administration, the Middle East, and the Kurds. Strategic Assessment. 2017; 20(1): 47-57.

13. Josheph D. Popular Struggle, Imperial Betrayal: The Kurdish Crisis in Iraq and Syria. Against the Current. 2018; 32(6) 12-30. 